Gut, 1967, 8, 276

\title{
Effect of 1-hyoscyamine on gastric secretion of acid and intrinsic factor in $\operatorname{man}^{1}$
}

\author{
G. DOTEVAlL, A. WALAN, AND A. WEINFELD \\ From the first Medical Service, Sahlgren's Hospital, University of Göteborg, Göteborg, Sweden
}

EDITORIAL COMMENT It has been suggested that intrinsic factor, like pepsin, is stored in the mucosa and that histamine and some cholinergic agents produce an increased secretion by an early 'wash-out' mechanism. This study provides further evidence in support of this concept.

The detection of immunological phenomena in pernicious anaemia (Schwartz, 1958; Taylor, 1959) introduced the concept of immunological assay of intrinsic factor. Several methods in which antibodies against intrinsic factor are used are now available (Jeffries and Sleisenger, 1965; Herbert, Gottlieb, Lau, and Wasserman, 1964; Abels, Bouma, Jansz, Woldring, Bakker, and Nieweg, 1963; Ardeman Chanarin, 1965), and the aim of this investigation has been to study gastric secretion of acid and intrinsic factor after stimulation by histamine infusion both before and during treatment with 1-hyoscyamine.

\section{MATERIAL}

The studies were carried out on seven male patients with chronic duodenal ulcer without haematological abnormalities. All were investigated basally and after stimulation by histamine infusion. During the first test all drugs had been withdrawn for at least three days. The patients were investigated before and during treatment with sustained-release tablets of 1-hyoscyamine in optimal effective doses, which is the highest tolerable dose not giving any disturbing side effects (Sun and Shay, 1956). L-hyoscyamine is the most active component of atropine, which is the racemic form, d-1-hyoscyamine. L-hyoscyamine in tablets with sustained release has previously been shown to have a prolonged effect on gastric secretion of acid and gave a reduction of $61 \%$ of basal secretion of acid up to eight hours after oral administration (Dotevall and Walan, 1965). The optimal effective dose varied between 0.2 and $1.0 \mathrm{mg}$ l-hyoscyamine with a mean of $0.57 \mathrm{mg}$. When the optimal dose was reached, this dose was maintained for three weeks before the second investigation was made. On the day of investigation, 1-hyoscyamine was given two hours before performance of the test. Both investigations were carried out in the same way and as described below.

${ }^{1}$ This work was supported by the Swedish Medical Research Council (project no. B67-19x-779-02).
METHODS

The patients were examined at 8.00 a.m. after fasting for at least 12 hours. A nasogastric tube of $3 \mathrm{~mm}$. internal diameter was passed into the stomach, the patient sitting in a semiupright position. The stomach was drained continuously by suction at a subatmospheric pressure of $50 \mathrm{~mm}$.Hg. Extra suction and injection of air were achieved by means of a syringe. At the end of each period, the patient was instructed to take deep inspirations in order to empty the stomach completely. At the beginning of the investigation $100 \mathrm{mg}$. antazoline was given by intramuscular injection.

After removal of the residual secretion from the stomach a 30-minute collection of basal secretion was made. Histamine was then given intravenously with an infusion pump, according to a method described elsewhere (Dotevall and Walan, 1967). Secretions were collected during histamine infusion for six 15-minute periods. The infusion speed was increased in every period. The following doses of histamine dihydrochloride were thus given: $0.0021,0.0037,0.0066,0.0117,0.0210$, and 0.0354 $\mathrm{mg} . / \mathrm{kg}$. body weight $/ 15$ minutes.

Samples of gastric juice were taken from each specimen for determination of acid and intrinsic factor. The samples for intrinsic factor assay were neutralized with $10 \mathrm{~N}$ sodium hydroxide to $p \mathrm{H} \mathrm{7,} \mathrm{centrifuged} \mathrm{to} \mathrm{remove} \mathrm{mucus,}$ and stored at $-20^{\circ} \mathrm{C}$. before assay.

Hydrogen ion activity was determined potentiometrically in a Beckman $p \mathrm{H}$ meter. The gastric juice was titrated with $\mathrm{N} / 10 \mathrm{NaOH}$ until $p \mathrm{H} \mathrm{7.0.} \mathrm{The} \mathrm{results} \mathrm{are}$ given as $\mathrm{mEq}$. $\mathrm{HCl} / 15 \mathrm{~min}$.

ASSAY OF INTRINSIC FACTOR Intrinsic factor activity was determined as described by Ardeman and Chanarin (1965) using $\mathrm{Co}^{57} \mathrm{~B}_{12}$ as the radioactive isotope. Intrinsic factor is determined as the difference between total vitamin $\mathbf{B}_{\mathbf{1 2}^{-}}$ binding capacity and the vitamin $\mathbf{B}_{12}$-binding capacity after complete blockage of intrinsic factor with excess of antibodies against intrinsic factor. One unit of intrinsic factor was defined as the specific intrinsic factor binding of $1 \mathrm{ng}$. vitamin $\mathrm{B}_{12}$. 
The significance of differences between groups was tested with Student's $t$ test and differences below the $5 \%$ level were regarded as significant.

\section{RESULTS}

VOLUME OF BASAL SECRETION The volume of gastric juice during the basal period was $26.7 \pm 6.2 \mathrm{ml} . / 15$ min. before treatment (six patients) and 18.8 $\pm 4 \cdot 2$ $\mathrm{ml} . / 15 \mathrm{~min}$. during treatment with 1-hyoscyamine (Table I).

\section{TABLE I}

VOLUME OF GASTRIC JUICE (ml.)

BASALLY AND AFTER STIMULATION WITH INCREASING DOSES OF HISTAMINE BEFORE AND DURING TREATMENT WITH l-HYOSCYAMINE

Patient $\begin{aligned} & \text { l-Hyoscy- } \\ & \begin{array}{l}\text { amine } \\ \text { (mg.) }\end{array}\end{aligned} \quad \begin{aligned} & \text { Basal } \\ & \text { 15-min. }\end{aligned}$ Value $\frac{\text { Histamine }(\mathrm{HCl} \text { mg./kg./15 min.) }}{0.00210 .00370 .00660 .01170 .02100 .0354}$ Before Treatment

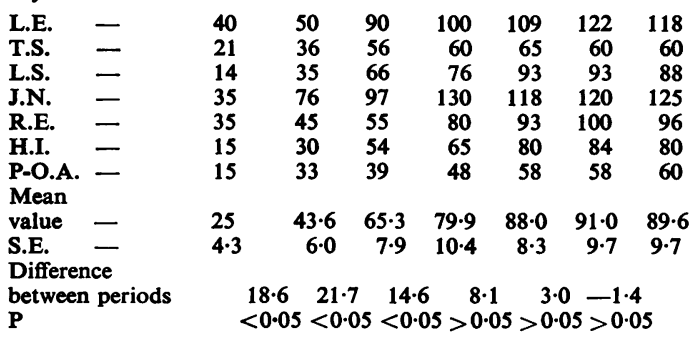

During Treatment with Optimal Doses of l-Hyoscyamine

\begin{tabular}{|c|c|c|c|c|c|c|c|c|}
\hline E. & 0.2 & 40 & 51 & 62 & 75 & 100 & 108 & 105 \\
\hline & & & 15 & 30 & 37 & 45 & 50 & 50 \\
\hline S. & 1.0 & 5 & 15 & 33 & 36 & 52 & 71 & 52 \\
\hline N. & 0.6 & 22 & 78 & 100 & 101 & 110 & 115 & 140 \\
\hline. $\mathrm{E}$ & 1.0 & 10 & 21 & 32 & 43 & 59 & 60 & 91 \\
\hline & 0.4 & - & 15 & 2. & 44 & J & 66 & 68 \\
\hline . & $0 \cdot 4$ & 30 & 28 & 40 & 44 & 54 & 63 & 67 \\
\hline & & $18 \cdot 8$ & $31 \cdot 1$ & 46.0 & $54 \cdot 3$ & 68.0 & $76 \cdot 1$ & 81.9 \\
\hline & 0.57 & $4 \cdot 2$ & $9 \cdot 3$ & $10 \cdot 1$ & $9 \cdot 2$ & 9.8 & 9.5 & 12. \\
\hline & & & 05 & & 0 & $\begin{array}{l}13.7 \\
-0.05\end{array}$ & $\begin{array}{l}8.1 \\
=0.05<\end{array}$ & $\begin{array}{r}5.8 \\
50.0\end{array}$ \\
\hline
\end{tabular}

VOLUME OF SECRETION AFTER HISTAMINE STIMULATION The volume of gastric juice increased successively in the first three periods of histamine stimulation. Despite a threefold increase of histamine from the fourth to the sixth period, no further increase in volume could be noted. The differences between periods were $21 \cdot 7,14 \cdot 6,8 \cdot 1,3 \cdot 0$, and $-1 \cdot 4 \mathrm{ml}$. During treatment with 1-hyoscyamine, there was a marked reduction in volume when compared with the pretreatment values. With increasing doses of histamine there was in contrast to the results before treatment a continuous increase in volume except between the last two periods. The differences between periods

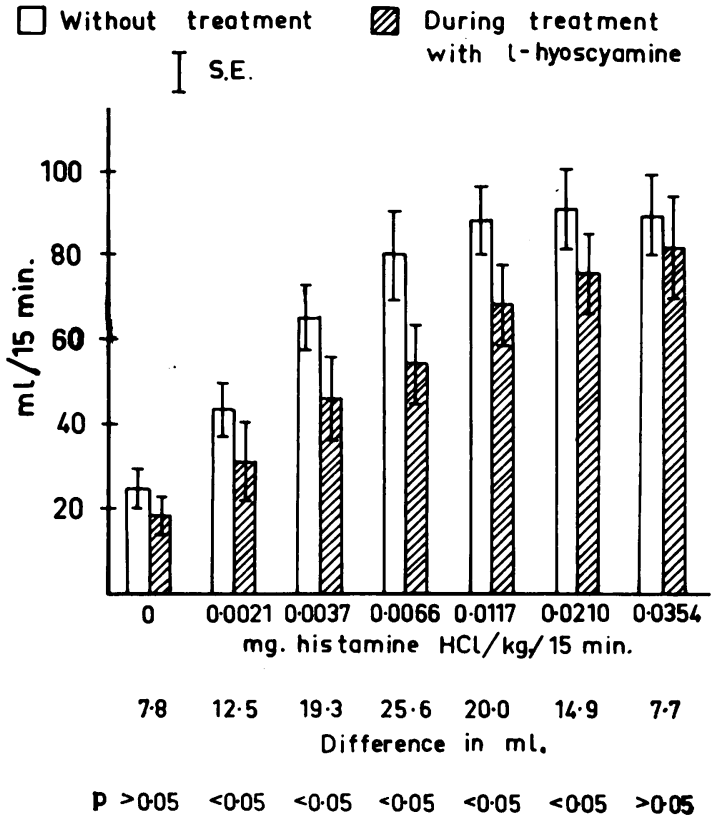

FIG. 1. Diagram illustrating volumes of gastric juice secreted with and without l-hyoscyamine.

were $14 \cdot 9,8 \cdot 3,13 \cdot 7,8 \cdot 1$, and $5 \cdot 8 \mathrm{ml}$. Compared with the pre-treatment values a decrease in volume could be noted in all periods except in the last. The decrease in volume was most pronounced during stimulation with moderate doses of histamine (Fig. 1).

BASAL ACID SECRETION The basal secretion of acid was $1.56 \pm 0.36 \mathrm{mEq} . / 15 \mathrm{~min}$. before treatment (six patients and $1.02 \pm 0.52 / 15 \mathrm{~min}$. during treatment with 1-hyoscyamine) (Table II). The secretion of acid was decreased to $65 \%$ of the pre-treatment value.

SECRETION OF ACID AFTER HISTAMINE STIMULATION Before treatment there was a steady increase in hydrochloric acid output with increasing doses of histamine (Table II), and it was statistically significant between the first three periods. The differences were less pronounced in the last three periods. The differences between periods were $3.45,2 \cdot 22,1 \cdot 13$, 0.41 , and $0.22 \mathrm{mEq}$. $\mathrm{HCl} / 15 \mathrm{~min}$. After treatment with 1-hyoscyamine the secretion of acid decreased. Compared with the pre-treatment values, the decrease was most pronounced with low and moderate doses of histamine. With the highest dose of histamine, there was no statistically significant difference between the values obtained before and during treatment (Fig. 2). Even with anticholinergic treatment there was a steady increase in acid secretion when 
TABLE II

HYDROCHLORIC ACID OUTPUT IN GASTRIC JUICE (mEq.) BASALLY AND AFTER STIMULATION WITH INCREASING DOSES OF HISTAMINE BEFORE AND DURING TREATMENT WITH l-HYOSCYAMINE

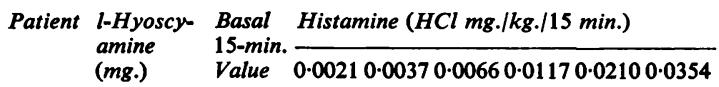
Before Treatment

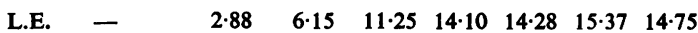

$\begin{array}{lllllllll}\text { L.E. } & - & 1.26 & 3.60 & 6.55 & 7.20 & 9.36 & 7.68 & 7.50\end{array}$

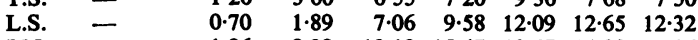

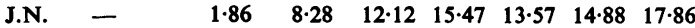

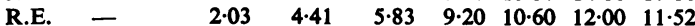

$\begin{array}{lllllllll}\text { H.I. } & - & 0.60 & 1.74 & 4.97 & 6.70 & 9.12 & 9.16 & 10.00\end{array}$

$\begin{array}{llllllll}\text { P-O.A. - } & 0.60 & 1.49 & 3.90 & 4.94 & 6.09 & 6.20 & 5.52\end{array}$

Mean

value - $\begin{array}{llllllll} & 1.42 & 3.94 & 7.38 & 9.60 & 10.73 & 11.13 & 11.35\end{array}$

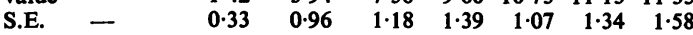

Difference

$\begin{array}{lllllll}\text { between periods } & 2.52 & 3.45 & 2.22 & 1.13 & 0.41 & 0.22\end{array}$

P

$<0.05<0.05<0.05>0.05>0.05>0.05$

During Treatment with Optimal Doses of l-Hyoscyamine.

\begin{tabular}{|c|c|c|c|c|c|c|c|c|}
\hline $\begin{array}{l}\text { L.E. } \\
\text { T.S. } \\
\text { L.S. } \\
\text { J.N. } \\
\text { R.E. } \\
\text { H.I. } \\
\text { P-O.A. }\end{array}$ & $\begin{array}{l}0.2 \\
0.4 \\
1.0 \\
0.6 \\
1.0 \\
0.4 \\
0.4\end{array}$ & $\begin{array}{l}3.44 \\
0.11 \\
0.15 \\
1.16 \\
0.29 \\
\overline{0 .}\end{array}$ & $\begin{array}{l}6.78 \\
0.60 \\
0.78 \\
9.59 \\
0.84 \\
0.51 \\
2.08\end{array}$ & $\begin{array}{r}7.87 \\
1.06 \\
3.30 \\
13.00 \\
2.05 \\
2.10 \\
3.40\end{array}$ & $\begin{array}{r}10 \cdot 50 \\
4 \cdot 37 \\
4 \cdot 25 \\
12.63 \\
3.44 \\
4 \cdot 75 \\
4 \cdot 40\end{array}$ & $\begin{array}{r}14 \cdot 70 \\
5 \cdot 18 \\
6 \cdot 29 \\
11 \cdot 00 \\
5.90 \\
5.88 \\
5 \cdot 13\end{array}$ & $\begin{array}{r}14.80 \\
5.50 \\
8.24 \\
12.65 \\
6.60 \\
8.58 \\
5.54\end{array}$ & $\begin{array}{r}14.91 \\
6.35 \\
6.24 \\
16.52 \\
10.92 \\
8.64 \\
5.96\end{array}$ \\
\hline $\begin{array}{l}\text { value } \\
\text { S.E. }\end{array}$ & 0.57 & $\begin{array}{l}1.02 \\
0.52\end{array}$ & $\begin{array}{l}3.03 \\
1.38\end{array}$ & $\begin{array}{l}4.68 \\
1.62\end{array}$ & $\begin{array}{l}6 \cdot 33 \\
1 \cdot 38\end{array}$ & $\begin{array}{l}7 \cdot 73 \\
1 \cdot 39\end{array}$ & $\begin{array}{l}8.84 \\
1.36\end{array}$ & $\begin{array}{l}9.93 \\
1.64\end{array}$ \\
\hline 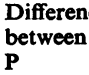 & & & $=0$ & -0 & 0 & 1 & $\begin{array}{l}1.0 \\
0.0\end{array}$ & \\
\hline
\end{tabular}

higher doses of histamine were given. The differences between periods were $1 \cdot 66,1 \cdot 65,1 \cdot 40,1 \cdot 12$, and $1 \cdot 09$, mEq. $\mathrm{HCl} / 15$ min. (Table II).

INTRINSIC FACTOR Secretion of intrinsic factor followed a different pattern from that of volume and hydrochloric acid. Without treatment the basal secretion of intrinsic factor was $617 \pm 157$ units $/ 15$ min. (six patients) (Table III). The output of intrinsicfactor increased after histaminestimulation to a maximum of $3,970 \pm 1,047$ units $/ 15 \mathrm{~min}$., which was reached in the third period of histamine stimulation. Then there was a steady decrease of intrinsic factor output in spite of a much higher histamine dose. Thus in the first period of histamine stimulation, the output of intrinsic factor was $3,791 \pm 596$ units, while in the last period with the largest amount of histamine infused the secretion of intrinsic factor was $2,158 \pm 614$ units. The amount of intrinsic factor secreted in the last period was, however, significantly higher than during the basal period.

After treatment with 1-hyoscyamine the basal output of intrinsic factor was $1,259 \pm 517$ units/15 min. The output after stimulation with histamine increased to a maximum of $4,030 \pm 711$ units $/ 15 \mathrm{~min}$.,

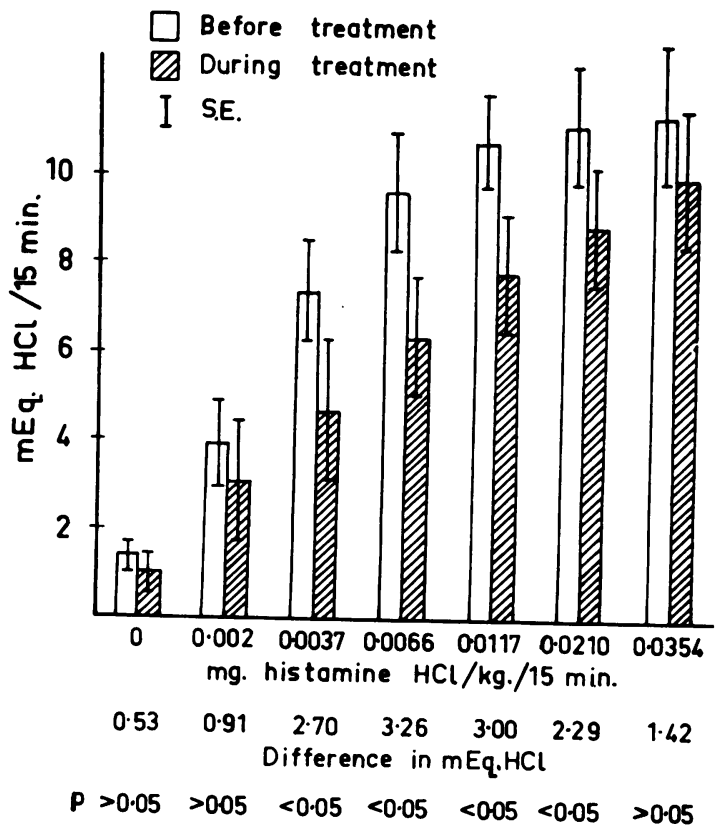

FIG. 2. Values for acid secretion before and during treatment.

\section{TABLE III}

INTRINSIC FACTOR OUTPUT IN GASTRIC JUICE BASALLY AND DURING STIMULATION WITH HISTAMINE IN INCREASING DOSES BEFORE AND DURING TREATMENT WITH 1-HYOSCYAMINE

Patient l-Hyoscy- Basal Histamine (HCl mg./kg.15 min.) amine 15-min.

(mg.) Value 0.00210 .00370 .00660 .01170 .02100 .0354

Before Treatment

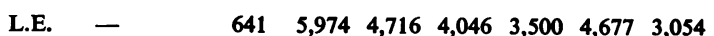

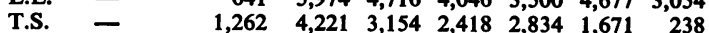

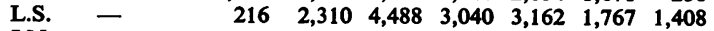

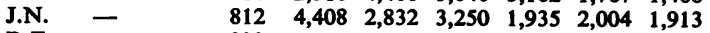

R.E. - $\quad 292 \quad 5,175 \quad 6,49010,000 \quad 6,603 \quad 7,800 \quad 5,280$

$\begin{array}{lllllllll}\text { H.I. } & - & 291 & 1,680 & 2,500 & 1,625 & 1,600 & 1,352 & 1,176\end{array}$

$\begin{array}{llllllll}\text { P-O.A. - } & 480 & \mathbf{2 , 7 7 2} & 234 & \mathbf{3 , 4 0 8} & \mathbf{1 , 5 6 6} & \mathbf{2 , 0 3 0} & \mathbf{2 , 0 4 0}\end{array}$

Mean

value - $\quad \begin{array}{llllllll} & 571 & 3,791 & 3,488 & 3,970 & 3,029 & 3,043 & 2,158\end{array}$

$\begin{array}{llrrrrrr}\text { S.E. } \quad- & 141 & 596 & 750 & 1,047 & 662 & 897 & 614\end{array}$

During Treatment with Optimal Doses of l-Hyoscyamine

$\begin{array}{lllllllll}\text { L.E. } & 0.2 & 3,320 & 5,230 & 5,377 & 5,803 & 7,323 & 2,914 & 2,581\end{array}$

$\begin{array}{lllllllll}\text { T.S. } & 0.4 & 495 & 330 & 3,990 & 3,626 & 3,060 & 3,200 & 2,150\end{array}$

$\begin{array}{llllllllll}\text { L.S. } & 1.0 & & 950 & 750 & 858 & 1,944 & 2,184 & 2,272 & 1,820\end{array}$

$\begin{array}{lllllllll}\text { J.N. } & 0.6 & 540 & 1,950 & 2,300 & 1,616 & 2,200 & 1,840 & 1,400\end{array}$

$\begin{array}{lllllllll}\text { R.E. } & 1.0 & 0 & 78 & 5,936 & 5,934 & 5,829 & 5,328 & 5,851\end{array}$

$\begin{array}{llllllllll}\text { H.I. } & 0 \cdot 4 & - & 1,380 & 3,750 & 5,940 & 4,536 & 3,960 & 2,924\end{array}$

$\begin{array}{llllllll}\text { P-O.A. 0.4 } & \mathbf{2 , 2 5 0} & \mathbf{3 , 3 3 2} & \mathbf{3 , 4 8 0} & \mathbf{3 , 3 4 4} & \mathbf{2 , 9 7 0} & \mathbf{1 , 5 7 5} & \mathbf{1 , 2 0 6}\end{array}$

Mean

$\begin{array}{lllllllll}\text { value } & 0.57 & 1,259 & 1,864 & 3,670 & 4,030 & 4,015 & 3,013 & 2,562\end{array}$

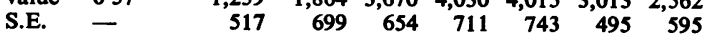




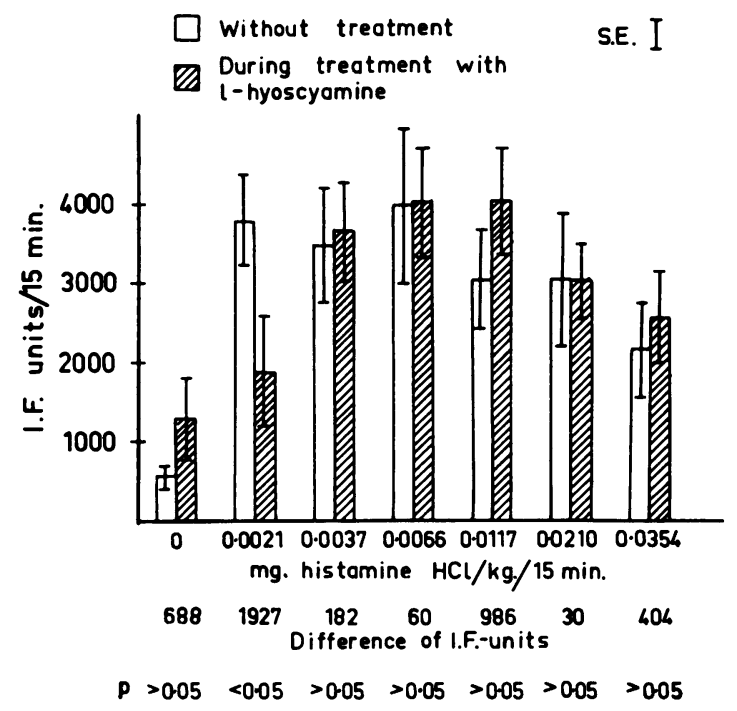

FIG. 3. Values for excretion of intrinsic factor without treatment and during treatment with l-hyoscyamine.

which was noted in the third period of histamine stimulation. Then there was a slight decrease in intrinsic factor output. This decrease was less pronounced than before treatment. Mean of total output of intrinsic factor during histamine stimulation before treatment was $19,479 \pm 4,117$ units and during treatment with optimal effective doses of l-hyoscyamine $19,153 \pm 1,221$ units. Thus there was no difference in total output.

\section{DISCUSSION}

The infusion of histamine in increasing doses has been shown elsewhere (Dotevall and Walan, 1967) to give higher values of acid output than the augmented histamine test according to Kay (1953). It probably offers a better opportunity to study the inhibitory effect of different drugs than the augmented histamine test or the constant histamine-infusion test of Lawrie, Smith, and Forrest (1964). The degree of inhibition of volume and acid output in basal secretion after treatment with optimal doses of 1hyoscyamine was $30 \%$ and $34 \%$ respectively. This is less than we have observed before (Dotevall and Walan, 1965). In the present investigation the mean dose of 1-hyoscyamine given before the investigation was $0.57 \mathrm{mg}$., while in the previous studies the mean dose was $0.8 \mathrm{mg}$.

After increasing doses of histamine, there was a continuous increase in volume and acid output. The increase in volume in the last periods of histamine stimulation was less than that of acid. This result could also be expected, as it is known that acid concentration increases with increasing volumes in the same individual.

During treatment with optimal effective doses of l-hyoscyamine there was a marked reduction of volume and acid output during histamine stimulation. The reduction was most pronounced in the third period of histamine stimulation when the difference against the values obtained before treatment was $25.6 \mathrm{ml}$. and $3.26 \mathrm{mEq}$. $\mathrm{HCl}$ respectively. With higher stimulation this difference diminished and in the last period of histamine stimulation there was no statistically significant difference either for volume or for acid. The maximal capacity to secrete volume as well as acid was thus not diminished, despite three weeks' treatment with optimal doses of a long-acting anticholinergic drug. If there is a correlation between the number of parietal cells and acid output capacity (Card and Marks, 1960), this must mean that there is no reduction in the number of parietal cells during treatment with anticholinergics. Hood and Code (quoted by Gregory, 1962) in their animal studies on gastric secretion before and after vagotomy found that the maximal secretory response was unchanged after vagotomy. However, the amount of histamine required to produce a maximal response was much greater after vagotomy than before.

The secretory pattern for intrinsic factor was quite different. Before treatment there was already a pronounced increase in intrinsic factor output in the first period of histamine stimulation. The output was highest in the first three periods. The lowest value during histamine stimulation was noted in the last period, when the highest dose of histamine was given. The output in this period was, however, about three times as high as in the basal period. The same values have been found in a larger group of patients studied during the same conditions (Dotevall, Walan, and Weinfeld, 1967). During treatment with 1-hyoscyamine the output of intrinsic factor during the basal period was higher than without treatment $(1,259$ and 617 units respectively). Stimulation with histamine during treatment gave a less pronounced increase in intrinsic factor output in the first period. The difference in output in this period before and during treatment was 1,927 units and was statistically significant. The output increased in the next three periods, after which a moderate decrease was noted. The total output of intrinsic factor during histamine stimulation was the same before and during treatment with 1hyoscyamine and the only difference that could be noted was the slower reaction to histamine stimulation when l-hyoscyamine had been given. It is interesting to compare the present results with the findings of Bitsch, Christiansen, Faber, and Rødbro (1966) who found a pronounced decrease of intrinsic 
factor output after vagotomy both basally and after the augmented histamine test.

Jeffries and Sleisenger (1965) and Bitschet al.(1966) have proposed that intrinsic factor, like pepsin, is stored in the mucosa and that histamine, histalog, and some cholinergic agents produce an increased secretion by an early 'wash-out' mechanism. Jeffries and Sleisenger (1965) explain the continued secretion with the lower output (but still above the basal level) by a mucosal synthesis. This would imply a stimulation of intrinsic factor synthesis by histamine. The different secretory pattern between intrinsic factor and hydrochloric acid and volume that we have observed is well explained by such a 'wash-out' theory. The significant increase in intrinsic factor output in the last period after more than one hour of histamine stimulation compared to the basal period suggests that a histamine-stimulated synthesis might occur.

\section{SUMMARY AND CONCLUSIONS}

Volume, hydrochloric acid output, and intrinsic factor output have been studied in human gastric juice basally and after infusion with increasing doses of histamine before and during treatment with 1hyoscyamine. The volume of gastric juice increased successively in the first four periods of histamine stimulation. Despite a threefold increase in histamine dose from the fourth to the sixth period no further increase of volume was noted. The output of hydrochloric acid increased successively in the first five periods of histamine stimulation. During treatment with optimal effective doses of 1-hyoscyamine the volume and output of hydrochloric acid were lower basally and during stimulation with low doses of histamine. In the last period when the largest doses of histamine were given there was, however, no change in output when compared to the pre-treatment values.

The immunological method for intrinsic factor determination introduced by Ardeman and Chanarin (1965) has been used. The output of intrinsic factor increased notably during the histamine infusion. The output was largest during the first 45 minutes of stimulation after which a slight decrease occurred. The output of intrinsic factor $75-90 \mathrm{~min}$. after beginning of histamine infusion was, however, still higher than during basal conditions. Treatment with optimal doses of l-hyoscyamine resulted in a higher output of intrinsic factor during the basal period but the increase during stimulation with low doses of histamine, which was very marked before treatment, was less pronounced during treatment. The total output of intrinsic factor was, however, not changed during treatment with 1-hyoscyamine for a period of three weeks.

The present findings are in agreement with the suggestions of a 'wash-out' phenomenon for intrinsic factor secretion after stimulation with histamine. The continued high output of intrinsic factor 75-90 min. after the beginning of a histamine infusion could be the result of a late 'wash-out'-response or a direct stimulatory effect by histamine on intrinsic factor production.

\section{REFERENCES}

Abels, J., Bouma, W., Jansz, A., Woldring, M. G., Bakker, A., and Nieweg, H. O. (1963). Experiments on the intrinsic factor antibody in serum from patients with pernicious anemia. J. Lab. clin. Med., 61, 893-906

Ardeman, S., and Chanarin, I. (1965). Assay of gastric intrinsic factor in the diagnosis of Addisonian pernicious anaemia. Brit. $J$. Haemat., 11, 305-314.

Bitsch, V., Christiansen, P. M., Faber, V., and Rødbro, P. (1966), Gastric secretory patterns before and after vagotomy. Lancet, 1 , 1288-1291.

Card, W. I., and Marks, I. N. (1960). The relationship between the acid output of the stomach following 'maximal' histamine stimulation and the parietal cell mass. Clin. Sci., 19, 147-163.

Dotevall, G., and Walan, A. (1965). The effect of l-hyoscyamine in tablets with sustained release on gastric secretion of acid in man. Acta med. scand., 178, 759-764.

- - (1967). Gastric secretion of acid after intravenous infusion of histamine in large doses. Ibid., 181, 439-444.

- - , and Weinfeld, A. (1967). Gastric secretion of acid and intrinsic factor during histamine infusion in man. Scand. J. Haemat. In the press.

Gregory, R. A. (1962), Secretory Mechanisms of the Gastro-Intestinal Tract. Arnold, London.

Herbert, V., Gottlieb, C., Lau, K.-S., and Wasserman, L. R. (1964). Intrinsic-factor assay. Lancet, 2, 1017-1018.

Jeffries, G. H., and Sleisenger, M. H. (1965). The pharmacology of intrinsic factor secretion in man. Gastroenterology, 48, 444-448.

Kay, A. W. (1953). Effect of large doses of histamine on gastric secretion of $\mathrm{HCl}$ : an augmented histamine test. Brit. med. J., 2, 77-80.

Lawrie, J. H., Smith, G. M. R., and Forrest, A. P. M. (1964). The histamine-infusion test. Lancet, 2, 270-273.

Makhlouf, G. M., McManus, J. P. A., and Card, W. I. (1965). A comparative study of the effects of gastrin, histamine, histalog, and mechothane on the secretory capacity of the human stomach in two normal subjects over 20 months. Gut, 6, 525-534.

Nordgren, B. (1963). The rate of secretion and electrolyte content of normal gastric juice. Acta physiol. scand., 58, suppl. 202.

Schwartz, M. (1958). Intrinsic-factor-inhibiting substance in serum of orally treated patients with pernicious anaemia. Lancet, 2, 61-62.

Sun, D. C. H., and Shay, H. (1956). Optimal effective dose of anticholinergic drug in peptic ulcer therapy. Arch. intern. Med., 97, 442-452.

Taylor, K. B. (1959). Inhibition of intrinsic factor by pernicious anaemia sera. Lancet, 2, 106-108. 